\title{
Effect of oxidant air pollutants on the respiratory system: insights from experimental animal research
}

\author{
P. Chitano*, J.J. Hosselet*, C.E. Mapp*, L.M. Fabbri**
}

Effect of oxidant air pollutants on the respiratory system: insights from experimental animal research. P. Chitano, J.J. Hosselet, C.E. Mapp, L.M. Fabbri. @ERS Journals Ltd. 1995

ABSTRACT: In the present paper, we have reviewed experimental animal studies on the effects of the two most important oxidant airborne pollutants, nitrogen dioxide and ozone, on the respiratory system.

The toxic effects depend on concentration and length of exposure, and are generally similar for both oxidants, with ozone operative at lower concentrations. High doses of both oxidants cause death due to lung oedema Exposure to sublethal levels causes functional alterations such as airflow limitation and airway hyperresponsiveness to bronchoconstrictor stimuli. These effects, which are generally reversible, are associated with epithelial injury, oedema and airway and parenchymal infiltration by inflammatory cells. Loss of cilia of airway epithelium and necrosis of type I alveolar epithelial cells are the most prominent consequences at the epithelial level. Inmation is characterized by early neutrophilic infiltration, followed by an increased number of mononuclear cells, predominantly alveolar macrophages.

After long-term exposure, whilst nitrogen dioxide causes predominantly emphysema, ozone produces mainly pulmonary fibrosis. Biochemical effects include lipid peroxidation, increased antioxidant metabolism, and alteration of enzyme activity. Nitrogen dioxide and ozone may also alter the immunological response and reduce the defence against infections, increasing the susceptibility of exposed animals to infections.

Eur Respir J., 1995, 8, 1357-1371.
*Institute of Occupational Medicine, University of Padova, Italy. **Institute of Infectious and Respiratory Diseases, University of Ferrara, Italy.

Correspondence: L.M. Fabbri

Istituto di Malattie lnfettive e dell'Apparato Respiratorio

Università degli Studi di Ferrara

Via Fossato di Mortara 23

44100 Ferrara

Italy

Keywords: Airways, lung, nitrogen dioxide, ozone

Received: April 291994

Accepted after revision March 1995

This work was funded in part by the NRCENEL Project-Interactions of Energy Systems with Human Health and Environment-Roma (Grant No. 2.1.3.), by the EC Biomed BMH1,-CT94-1284, by NRC Bilateral Project Italy-France, and by the Associazioniper lo Studio dei Tumori e delle Malattie Polmonari (ASTMP) and per la Ricerca e Cura dell Asma (ARCA).

\section{CONTENTS}

Introduction

Sources and distribution of oxidant air pollutants

Animal exposure and oxidant uptake

Toxicity

Effects on lung function and airway responsiveness

Lung function

Airway responsiveness

Histopathology

Structural damage
Lung oedema
Inflammatory response
Relationship between airway permeability and
airway inflammation

\section{Introduction}

Environmental pollution has become, in the last few decades, one of the most prominent concerns for human health. As demonstrated by serious incidents which
Relationship between airway inflammation and airway responsiveness

Emphysema and pulmonary fibrosis Repair

Biochemical alterations

Lipid peroxidation and antioxidative protective system Other enzymatic activity

Impairment of lung defence

Defence against infections

Immunological response

Synergistic effects

In-vitro studies

Cell culture and mediator release

Tissue function

Conclusions

occurred in the past, air pollution can represent a major health hazard and cause an increase in mortality of the exposed population, mainly due to bronchitis, pneumonia, and exacerbation of pre-existing heart or lung diseases [1-3]. 
The actual impact of pollutants on health is related to the extent of individual exposure, which depends on factors such as the location and character of the sources, the spread and properties of the pollutants, smoking habits of the individuals, and other activities that increase contact with hazardous substances $[4,5]$. All these factors need to be taken into account, especially in epidemicological studies [6, 7].

Experimental studies on humans allow carefully controlled exposures. Since subjects obviously cannot be exposed to unsafe levels of pollutants in these studies, low and short-term exposures are utilized, providing knowledge about the first stages of disease development only. Studies on animals are the most appropriate for the examination of the mechanisms underlying functional, structural and biochemical alterations caused by acute and/or chronic exposures to the widest range of pollutant concentrations. The major drawback of animal studies is species variability, often making extrapolation of animal results to man difficult. Both research on animals and data from human experimental and epidemiological studies are, therefore, complementary in our understanding of lung injury induced by air pollutants, and taken together, may contribute to improve prevention and management [7, 8].

In the present review, we analyse experimental studies on animals, focusing on nitrogen dioxide $\left(\mathrm{NO}_{2}\right)$ and ozone $\left(\mathrm{O}_{3}\right)$, since these two oxidants are the most common airborne pollutants, and have been shown to have several severe adverse respiratory effects.

\section{Sources and distribution of oxidant air pollutants}

The release of potentially toxic chemicals into the air can result both from natural and anthropogenic events. The level they reach in a given environment is dependent on the number and location of sources, on the quantity of pollutants released, and on their subsequent fate in the air. Because of the number of different sources, $\mathrm{NO}_{2}$ and $\mathrm{O}_{3}$ reach highest concentrations in urban areas $[9,10]$.

Nitrogen dioxide is formed by the oxidation of nitrogen oxide, that is generated from oxygen and nitrogen by processes involving high temperatures. It is a product of most operations requiring combustion, and is present in motor vehicle emissions [9]. $\mathrm{NO}_{2}$ is also a major component of indoor air pollution, as it is generated by cigarette smoking and during the combustion of natural gas and kerosene, frequently used as energy sources for cooking and heating $[5,11]$.

Ozone forms naturally at high altitudes (above $20 \mathrm{~km}$ ) as a result of the action of ultraviolet radiation on molecular oxygen, which dissociates to oxygen radicals, that in turn react with other oxygen molecules to form $\mathrm{O}_{3}$. The energy of ultraviolet radiation which penetrates at lower altitudes is not sufficient to dissociate molecular oxygen, but is enough to dissociate $\mathrm{NO}_{2}$, when present, to form nitrogen oxide and oxygen radicals. In these conditions, the reaction between oxygen radicals and molecular oxygen to form $\mathrm{O}_{3}$ may also occur at ground level. Moreover, the release of unburnt hydrocarbons by combustion processes may further oxidize nitric oxide, increasing the level of $\mathrm{NO}_{2}$ and, consequently, the $\mathrm{O}_{3}$ concentration in the air $[10,12]$.

Once toxic air pollutants are produced or released, their environmental concentration varies according to transport and diffusion from the source and the extent and velocity of the transformations they undergo [5, $9,10,12] . \mathrm{NO}_{2}$ environmental concentration generally remains under 5 parts per billion (ppb) in rural zones, whereas it ranges between 10-75 ppb, with peak values of up to $500 \mathrm{ppb}$ in urban areas, both outdoors and indoors $[5,9]$. It reaches extremely high values (up to 500 parts per million (ppm)) in those zones of workplaces where welding arcs or blow torches are employed [13]. The level reached by $\mathrm{O}_{3}$ is normally under 50 $\mathrm{ppb}$ in unpolluted air, whilst concentrations of up to $700 \mathrm{ppb}$ have been found in the air of polluted cities $[9,12]$.

Present recommendations state that the levels of environmental $\mathrm{NO}_{2}$ should not exceed 210 and $80 \mathrm{ppb}$ for more than 1 and $24 \mathrm{~h}$, respectively, [14]. Occupational threshold limit values (TLVs) for $\mathrm{NO}_{2}$ vary in different countries between 1-5 ppm time-weighted average (TWA) concentration, and between 3-10 ppm short-term exposure limit (STEL) [15]. $\mathrm{O}_{3}$ in the general environment should not reach concentrations higher than 100 and 60 ppb for more than 1 and $8 \mathrm{~h}$, respectively, [14], whilst occupational TLVs for $\mathrm{O}_{3}$ are $100 \mathrm{ppb}$ TWA and 300 ppb STEL [15].

\section{Animal exposure and oxidant uptake}

The levels and kinds of hazard which develop at a given target site depend on the amount of pollutant and on the contact time at that site. Therefore, to estimate the potential effects of air pollutants, those factors which contribute to exposure and uptake need to be carefully considered. Control of pollutant concentration and length of exposure are easily achieved in experimental studies. Once these are fixed, several other factors may affect the dose of a given pollutant that reaches a specific site of the respiratory system. Spontaneous breathing through the nose or the mouth and mechanical ventilation are two experimental conditions in which the surface of respiratory system exposed to the inspired air is greatly different: intubation permits a higher concentration of pollutant to reach central and peripheral airways. Exercise is a further condition which, mainly altering the ventilation, changes the dose of pollutant delivered to a given site. The anatomy and mechanics of the lung vary greatly from species to species and, thus, the pollutant uptake may also vary greatly in different species $[7,8,16,17]$.

The distribution of a gaseous component of inhaled air within the respiratory system also depends on the physicochemical properties of that component, particularly on its solubility and reactivity [8, 16-18]. A soluble gas is quickly removed from inspired air into the first tissue it meets, so that its uptake occurs predominantly in the upper airways. By contrast, the uptake of insoluble gases is due mainly to their reactivity, which is related to substrate availability and exposed surface, and is, therefore, more uniformly distributed along the respiratory system. 
Since $\mathrm{O}_{3}$ and $\mathrm{NO}_{2}$ are gases with low solubility, they are poorly absorbed by the airway mucosa [16-18]. Nevertheless they are very reactive molecules and their uptake in the respiratory system is extremely high [19-22]. Experimental measurements performed in dogs have shown that the uptake of $\mathrm{O}_{3}$ in the upper airways may be as high as $70 \%$ of the inspired quantity at $0.3 \mathrm{ppm}$ concentration and 4.5 $\mathrm{L} \cdot \mathrm{min}^{-1}$ flow, but it decreases to below $30 \%$ at a concentration and flow of $0.8 \mathrm{ppm}$ and $40 \mathrm{~L} \cdot \mathrm{min}^{-1}$, respectively. $\mathrm{O}_{3}$ uptake may be as high as $80 \%$ in the lower airways, where it is independent of inlet flow and concentration. Combining data for upper and lower airways, an extrathoracic removal of $\mathrm{O}_{2}$ of about $40 \%$ and a total uptake exceeding $90 \%$ has been estimated [19]. Slightly lower values of total absorption (almost $70 \%$ of inlet concentration) have been reported for $\mathrm{NO}_{2}$ in ventilated monkeys and in isolated rat lung [21, 22].

Mathematical dosimetry models have been developed to explain, simulate, and predict regional uptake of inhaled gases $[12,17,18]$. These theoretical models take into account lung anatomy and mechanics, and the physicochemical properties of the respiratory system as well as of gas pollutants. Comparison between experimental data and predicted values have been used for the validation of the effectiveness of such models. The use of these models suggests that the uptake both of $\mathrm{NO}_{2}$ and $\mathrm{O}_{3}$ occurs to a similar extent between the trachea and the respiratory zone, and peaks at the terminal bronchioles.

Besides the site of absorption, several data reveal the role of chemical reactivity in the uptake and toxicity of these air pollutants.

Using $\mathrm{O}_{2}$ and oxygen, both labelled with ${ }^{18} \mathrm{O}$, it has been shown that $\mathrm{O}_{2}$ determines a 15,000 times greater uptake of $18 \mathrm{O}$, than molecular oxygen, and that tissues in closer contact with the inhaled gas (e.g. epithelium) carry a higher dose of ${ }^{18} \mathrm{O}[20,23] . \mathrm{O}_{3}$ absorption increases with temperature and is not dependent on vascular perfusion, suggesting that its uptake into the lung tissue is rate-limited by chemical reaction rather than by physical solubility [24]. In fact, whilst chemical reactivity increases with temperature, physical solubility decreases with temperature. In addition, solubility increases if the removal of solute is faster, e.g. when vascular perfusion of the lung is higher. Therefore, it is likely that $\mathrm{O}_{3}$ reacts entirely in the epithelium lining fluid, generating diffusing products such as aldehydes, hydrogen peroxide and free radicals, which in turn account for the toxic effects that follow $\mathrm{O}_{3}$ exposure $[18,23,25,26]$.

Like $\mathrm{O}_{3}, \mathrm{NO}_{2}$ uptake increases with temperature and is not dependent on vascular perfusion [21]. $\mathrm{NO}_{2}$ uptake occurs predominantly in the epithelium lining fluid [21, 23, 27-29], where $\mathrm{NO}_{2}$ reacts and produces nitrite, nitric and nitrous acids, which can themselves cause oxidative damage $[22,28,29]$. The formation of these products would explain some distinctive effects of $\mathrm{NO}_{2}$, such as those on mucociliary clearance and macrophage phagocytic activity in rabbits, which are intermediate between the effects exerted by a pure oxidant $\left(\mathrm{O}_{3}\right)$ and those exerted by a pure acid $\left(\mathrm{H}_{3} \mathrm{SO}_{4}\right)$ [29].

\section{Toxicity}

Several acute and chronic effects determined by oxidant gases have been reported, which affect function, structure, and biochemistry of the respiratory system, involving inflammatory and immunological responses.

Very high doses of $\mathrm{NO}_{2}$ cause the death of exposed animals in a few minutes $[13,30,31]$. In rats, the concentration which kills $50 \%$ of exposed animals after a given time of exposure $\left(\mathrm{LC}_{50}\right)$ is $1,445 \mathrm{ppm} \mathrm{NO}$ for 2 min of exposure, 416-833 ppm for $5 \mathrm{~min}$, and 115-168 ppm for $1 \mathrm{~h}$ of exposure $[30,31] . \mathrm{LC}_{50}$ for $1 \mathrm{~h}$ exposure is $21 \mathrm{ppm} \mathrm{O}_{3}$ in mice and rats, and $52 \mathrm{ppm} \mathrm{O}_{3}$ in guinea pigs [32].

Irrespective of the oxidant concentration and of the duration of exposure which give rise to the fatal event, for both oxidants the cause of death is attributed to acute lung oedema.

\section{Effects of lung function and airway responsiveness}

Exposure to low levels of $\mathrm{O}_{3}$ and $\mathrm{NO}_{2}$ may alter respiratory function in several animal species. These changes of lung function consist of increased respiratory frequency, decreased tidal volume, air trapping, airflow limitation, and increased airway responsiveness to contractile agents.

Lung function. Functional alterations have been reported after exposure to concentrations as low as $0.24-0.34$ ppm $\mathrm{O}_{3}$. Acute exposure increases respiratory frequency and decreases tidal volume [12,33-35]. These effects are inhibited by bilateral cooling of the cervical vagi. They have, therefore, been attributed to an altered sensitivity of the vagal bronchopulmonary receptors, most likely of $\mathrm{C}$-fibre endings and rapidly adapting irritant receptors [36], with increased reflex stimulation of the diaphragm through the phrenic nerve [37].

In addition, acute exposure to $\mathrm{O}_{3}$ may cause air trapping, as shown by increased functional residual capacity and increased closing volume. Air trapping is probably due to premature closure of the small peripheral airways. Ozone may also cause acute airflow limitation, as shown by increased airway resistance and reduced dynamic compliance. These acute obstructive effects quickly reverse after cessation of exposure [12, 38, 39]. Airflow limitation is also observed after chronic exposures, mainly caused by fibrotic lesions, and in these cases it persists after cessation of exposure [12].

$\mathrm{NO}_{2}$ exposure at concentrations of $0.8-5 \mathrm{ppm}$ has similar effects on mechanical lung parameters [13, 33, 40, 41]. The severity of these effects is influenced by the mode of exposure. Indeed, when compared to continuous exposure, a greater reduction of end-expiratory volume, vital capacity, and respiratory system compliance has been shown in mice chronically exposed to $1 \mathrm{~h}$ spikes of $0.8 \mathrm{ppm} \mathrm{NO}_{2}$ superimposed on a continuous baseline exposure to $0.2 \mathrm{ppm}$ [42].

Airway responsiveness. A reversible increase in airway responsiveness to several contractile agents is observed in animals after acute exposure to a concentration of $\mathrm{O}_{3}$ 
ranging $0.5-3 \mathrm{ppm}[35,38,43-52]$. Increased airway responsiveness to histamine has also been reported following exposure to $4 \mathrm{ppm}$ or higher concentrations of $\mathrm{NO}_{2}$ in guinea-pigs [53-54]. No study has been performed on the mechanisms of $\mathrm{NO}_{2}$-induced airway hyperresponsiveness, whereas several mechanisms have been shown to be involved in the $\mathrm{O}_{3}$-induced airway hyperresponsiveness.

Pretreatment with inhibitors of oxygen radical generation prevents the development of airway hyperresponsiveness to acetylcholine in dogs exposed to $\mathrm{O}_{3}$ [55]. This finding suggests that the generation of free radicals is involved.

The increased airway responsiveness to acetylcholine in dogs can also be inhibited by the administration of different anti-inflammatory agents: e.g. BW755C [56], an inhibitor of arachidonic acid metabolism; indomethain [57], a cyclooxygenase inhibitor; OKY-046 [58], a thromboxane synthase inhibitor; and ambroxol [59], a surfactant-stimulating agent, which has also been shown to inhibit phospholipase $\mathrm{A}$. In guinea-pigs, $\mathrm{O}_{3}$-induced airway hyperresponsiveness to methacholine is inhibited by OKY-046 and ONO-1078 (a receptor antagonist of leukotriene $\mathrm{C}_{4}$ and $\mathrm{D}_{4}\left(\mathrm{LTC}_{4}\right.$ and $\left.\mathrm{LTD}_{4}\right)$ ) [60]. These data suggest that oxygenation products of arachidonic acid play a role in $\mathrm{O}_{3}$-induced airway hyperresponsiveness to cholinergic stimuli.

Moreover, it has been reported that exposure of guineapigs to $0.1 \mathrm{ppm} \mathrm{O}_{3}$ causes an inhibition of lung cholinesterase activity, which may contribute to the development of cholinergic hyperresponsiveness [61].

A recent study on the guinea-pig has shown a further mechanism for the increased cholinergic responsiveness: a loss of function of $\mathrm{M}_{2}$ muscarinic neural receptors after $4 \mathrm{~h}$ of exposure to $2 \mathrm{ppm}$ of $\mathrm{O}_{3}$ [62]. These receptors normally act as feedback inhibitors on the release of acetylcholine from nerve endings, so that a potentiation of vagally-mediated bronchoconstriction occurs when they are inhibited.

The mechanisms responsible for cholinergic hyperresponsiveness may also apply to the $\mathrm{O}_{3}$-induced increased airway responsiveness to other stimuli. Indeed, pretreatment of dogs with atropine-sulphate aerosol or cooling blockade of conduction of the vagus nerves have been shown to reduce the $\mathrm{O}_{3}$-induced hyperresponsiveness to histamine, suggesting that this hyperresponsiveness may be mediated, at least in part, via cholinergic pathways [45]. However, in guinea-pigs exposed to $\mathrm{O}_{3}$. the development of lower airway hyperresponsiveness to intravenous administration of histamine is not suppressed by bilateral cervical vagotomy or by inhibitors of arachidonic acid metabolism [52], and thus noncholinergic components may also mediate the hyperresponsiveness to histamine.

The response to platinum, ovalbumin and Ascaris is enhanced by $\mathrm{O}_{3}$ in platinum-sensitized monkeys, ovalbumin-sensitized guinea-pigs and Ascaris-sensitized dogs, respectively, [48-51]. Like the hyperresponsiveness to intravenous histamine, the increase in airway responsiveness to Ascaris antigen induced by ozone in Ascaris suum allergic dogs is not inhibited by the thromboxanesynthase inhibitor OKY-046, suggesting that thromboxane may not be involved [48]. This same study showed an increased plasma histamine concentration after antigen challenge in animals exposed to $\mathrm{O}_{3}$ compared to control dogs. Since the release of histamine from mast cells is an important component of the smooth muscle response to allergen challenge, it is not surprising that the $\mathrm{O}_{3}$-induced hyperresponsiveness to a specific antigen shows similarity to the $\mathrm{O}_{3}$-induced hyperresponsiveness to histamine, i.e. a lack of involvement of arachidonic acid metabolites.

A further different mechanism might be responsible for the $\mathrm{O}_{3}$-induced airway hyperresponsiveness to substance P: a reduced activity of the neutral endopeptidase, the enzyme which cleaves substance $P$ in addition to other tachykinins $[47,63]$. Indeed, neutral endopeptidase activity in tracheal tissue homogenate is significantly reduced in the guinea-pig by $2 \mathrm{~h}$ of exposure to 3 ppm $\mathrm{O}_{2}$ [53].

\section{Histopathology}

A histological approach reveals the differences, resulting from the length and amount of exposure, in the patterns of either $\mathrm{NO}_{2}$ - or $\mathrm{O}_{3}$-induced lung injury. An exposure of between $1 \mathrm{~h}$ and 1 week, which is considered a short-term (acute) exposure, induces cell injury, lung oedema and inflammation, which may be reversed after cessation of the exposure. Some of these effects decline with time even upon continuation of the exposure. A long-term (chronic) exposure (from one month to years) can also induce irreversible lesions, such as emphysema and pulmonary fibrosis.

Structural damage. Structural damage is induced both by acute and chronic exposure to $\mathrm{NO}_{2}$ or $\mathrm{O}_{3}$, mainly affecting cells at the junctions of the terminal airways and the proximal alveolar regions. It includes loss of cilia and secretory granules, necrosis and sloughing of epithelium [12, 13, 41, 64-80].

The threshold concentrations of oxidants which cause structural alterations are related to duration of the exposure. In fact, the same structural changes may be caused by concentrations of $\mathrm{NO}_{2}$ and $\mathrm{O}_{3}$ of, respectively, 10 and $0.5 \mathrm{ppm}$ after acute exposures, and $1 \mathrm{ppm}$ of $\mathrm{NO}_{2}$ and $0.06 \mathrm{ppm}$ (with spikes of $0.25 \mathrm{ppm}$ ) of $\mathrm{O}_{3}$ after chronic exposures.

Loss of cilia in the terminal bronchioles is considered an early indicator of acute oxidant-induced injury, even though it is also consistently found after long-term exposure [41, 64-72]. Necrosis of airway epithelial ciliated cells in terminal airways and of type I alveolar epithelial cells in centriacinar regions constitutes the main cellular alteration $[65,69-76]$. Other morphological changes frequently reported are damage to tight junctions and to Clara cells and goblet cells, with loss of secretory granules $[66,71,72,79]$, as well as thickening of the epithelium and of the alveolar wall with hypertrophy and hyperplasia of epithelial cells, particularly Clara cells and alveolar type II cells [65-80]. After either subchronic or chronic exposure, hypertrophy of smooth muscle and endothelial cells, hyperplasia of goblet cells and accumulation of mucus are also found in respiratory bronchioles [65, 76-78].

These injuries may lead to accumulation of debris in the airway lumen, and, therefore, to bronchiolitis oblit- 
erans and obstructive inflammatory lesion in bronchioles, with narrowing of the small airways $[65,68,71$, 76, 78].

Lung oedema. Exposure to high concentrations of NO, or $\mathrm{O}_{3}$ cause acute fatal lung oedema. Lung oedema may also occur after exposure to sublethal levels. A macroscopic consequence of oedema formation after exposure to these two oxidants consists of increased lung volume and wet weight $[32,76,77,81]$. A sensitive index of lung oedema, which constitutes a common finding after exposure both to $\mathrm{NO}_{2}$ and $\mathrm{O}_{3}$, is the presence of serum proteins in the bronchoalveolar lavage fluid [82-85]. Alteration of epithelial and vascular permeability leading to oedema is particularly marked at small airway and alveolar levels [75, 85-88]. Morphological observations show mainly focal interstitial and intra-alveolar oedema [75,87], with the former more pronounced around arteries than airways or veins [89]. A strong correlation has been found between the degree of $\mathrm{NO}_{2}$ or $\mathrm{O}_{3}$ exposure and the amount of oedema observed both in the alveolar spaces [88, 89] and in peribronchiolar and perivascular tissue $[81,84,89]$. Oedema is more evident at an early stage of exposure [75, 90], but has also been reported after long-term exposure [78]; it reverses after cessation of exposure [84, 87, 88].

Inflammatory response. Inflammation is a common feature of the lung response to a variety of environmental noxious agents, and has been noted in many species after exposure to $\mathrm{O}_{3}$ or $\mathrm{NO}_{2}$ [49, 65, 81, 82, 91-95].

The activation of resident macrophages and the chemotaxis of inflammatory cells into the lung is determined by preformed and/or newly formed mediators released from different cells in response to injury. Activated alveolar macrophages and neutrophils generate oxidizing products, which interact with both proteinases and proteinase inhibitors, producing additional damage to connective tissue, endothelial and epithelial cells. This results in amplification of oedema, injury, airway responsiveness and inflammation [96-98]. Therefore the direct toxic effects of oxidant gases may be potentiated by the release of mediators and the production of oxidant species from inflammatory cells.

Inflammation caused by exposure to oxidants occurs both in the airways and in the pulmonary tissue and may be investigated with different techniques, e.g. bronchoalveolar lavage and histopathological examination of necropsy or biopsy specimens.

Several reports have shown that recruitment of different cell populations into the lung and the airways occurs at different time-points after exposure. Terminal bronchioles and alveolar regions have been described as the predominant, or at least the initial, site of cellular infiltration [66, 71, 80-82, 86, 95].

In rabbits, it has been shown that the number of cells obtained by bronchoalveolar lavage increases both after acute and subacute exposure to $\mathrm{O}_{3}$ (to 1.2 and $0.1 \mathrm{ppm}$, respectively), i.e. neutrophils increase predominantly at $24 \mathrm{~h}$ after exposure, and alveolar macrophages at 7 days after exposure [92]. The intravenous infusion of labelled neutrophils at different time-points after exposure to $0.96 \mathrm{ppm} \mathrm{O}_{3}$ has recently been used on Rhesus monkeys to demonstrate the time-course of migration into the lung [95]. The study showed that neutrophil migration, as revealed by bronchoalveolar lavage, is maximum $12 \mathrm{~h}$ after the exposure and returns to baseline within the next $12 \mathrm{~h}$; after migration, neutrophils persist in the airways for up to $72 \mathrm{~h}$, at which point they are reduced to a quarter of the maximum amount. Neutrophils and macrophages have been observed on the luminal surface and in the walls of terminal bronchioles, after 8 and 24 h of exposure, respectively [82, 95]. In the same studies total protein content in bronchoalveolar lavage was maximum at $24 \mathrm{~h}$, and lymphocytes migrated maximally about $72 \mathrm{~h}$ after the exposure.

Lymphocyte infiltration of the lung tissue as well as T-lymphocyte proliferation in lymph nodes and in bronchus-associated lymphoid tissue have been found in histological specimens after $\mathrm{O}_{3}$ exposure [99, 100]. These reports suggest that $\mathrm{T}$-cells may play a role in the host response to oxidant gases.

Increased protein concentration, neutrophils, lymphocytes and macrophages in bronchoalveolar lavage fluid and in lung tissue have also been reported after exposure to $\mathrm{NO}_{2}[66,81,86,91,101,102]$. In short-term exposure to $\mathrm{NO}_{2}$, patchy interstitial accumulation of neutrophils can be observed in the bronchial walls [86, 91]. The initial response to $30 \mathrm{ppm}$ of $\mathrm{NO}_{2}$ consists of a marked increase in neutrophils, with a peak after 2 days of exposure, whereas macrophage and lymphocyte infiltration is maximum after one week of exposure or more [102]. An influx of alveolar macrophages and lymphocytes has been reported following both acute and chronic exposure to $\mathrm{NO}_{2}[66,70]$, the degree of infiltration being dependent on gas concentration and duration of exposure $[81,86,101]$.

Relationship between airway permeability and airway inflammation. Tracheal permeability develops immediately after exposure to oxidant gases [83-88, 103-106] and reaches a peak at $8 \mathrm{~h}$ postexposure, whilst the number of polymorphonuclear leucocytes usually peaks at $12 \mathrm{~h}$ [103]. Rats rendered leukopenic with cyclophosphamide have a significant reduction in circulating and pulmonary leucocytes and in airway permeability induced by $\mathrm{O}_{3}$, and pretreatment with either the $\mathrm{LTD}_{4}$ antagonist FPL55712 or indomethacin also inhibits the $\mathrm{O}_{3}$ induced increase in permeability [104]. By contrast, when neutrophil depletion is obtained with a rabbit antirat neutrophil serum, neutrophil-depleted rats exposed to $1 \mathrm{ppm} \mathrm{O}_{3}$ have a significant increase of protein in bronchoalveolar lavage [85]. Moreover, cyclophosphamide, indomethacin and colchicine (an inhibitor of chemotaxis) prevent cell migration into the lung, but do not reduce airway permeability induced by $\mathrm{O}_{3}$ in mice [105]. These data suggest that cellular influx and increased lung permeability may be independent parts of the lung inflammatory response to $\mathrm{O}_{3}$.

Relationship between airway inflammation and airway responsiveness. After exposure to $\mathrm{O}_{3}$, the development of airway inflammation has a time-course similar to that of the development of airway hyperresponsiveness [93, 94]. Neutrophil depletion by hydroxyurea inhibits airway hyperresponsiveness in dogs [107]. Inhibition of $\mathrm{O}_{3}$ induced airway hyperresponsiveness by different 
agents has also been achieved, without a reduction of the number of inflammatory cells in the airway mucosa $[55,57-59]$. These results suggest that the inhibition of $\mathrm{O}_{3}$-induced airway hyperresponsiveness may be mediated by the inhibition of the release of mediators by inflammatory cells. The prevention of neutrophil migration by monoclonal antibodies against neutrophil adhesion molecules does not affect the $\mathrm{O}_{3}$-induced increase in airway responsiveness [108]. Moreover, exposure of guinea-pigs to $2.9 \mathrm{ppm} \mathrm{O}_{3}$ for $30 \mathrm{~min}$ increases airway responsiveness to methacholine at $1 \mathrm{~h}$, without signs of inflammation in bronchoalveolar lavage [44]. The same authors found bronchoalveolar neutrophilia at 3 and $6 \mathrm{~h}$ after exposure. From these reports it seems that noninflammatory cells are the most likely candidates either for the production of newly formed mediators or the release of preformed ones which determine the increase in airway responsiveness; inflammatory cells may still play a potentiating role in the development of airway hyperresponsiveness after exposure to $\mathrm{O}_{3}$.

Emphysema and pulmonary fibrosis. With long-term exposure to oxidants, emphysematous and fibrotic lesions have been reported. However, these chronic effects differ with oxidant agents. Indeed, chronic exposure to $\mathrm{NO}_{2}$ produces both fibrosis and emphysema of the lung, whereas emphysema-like injuries have not been described after $\mathrm{O}_{3}$ exposure.

In long-term exposure to $\mathrm{NO}_{2}$, the respiratory bronchiole segment increases in size and alveolar ducts and alveoli show focal enlargement with destruction of alveolar septa $[68,76,77,86]$, as in human centriacinar emphysema. Therefore, NO,-induced emphysema has been used as an animal model to study the disease process of emphysema [109, 110]. An increase in lung volume and a decrease of the number of interalveolar septa, which are considered as markers of emphysema, are observed within 3-6 weeks of exposure to $30 \mathrm{ppm} \mathrm{NO}_{2}$ $[86,111]$. Some of the above-reported studies have also shown that fibrotic lesions may be present in the lung, associated with the emphysematous ones, after longterm exposure to $\mathrm{NO}_{2}[77,86]$.

A regional structural remodelling of the central acinus has been observed after long-term exposure to $\mathrm{O}_{3}$ [78], which is characterized by fibroblast proliferation, thickening of the alveolar capillary membrane, increased synthesis and deposition of collagen in different regions of the lung, thicker walls and reduced internal diameter in terminal bronchioles, and fibrosis of interalveolar septa [32, 75, 78, 112, 113].

Repair. Once the exposure is over, most lesions caused by acute exposure to oxidant gases reverse. The reparative process may, in fact, start early during exposure. In alveoli, damaged epithelial cells are shed and are replaced by other cells, mainly type II cells [67, 69, 75, 114]. In bronchioles, Clara cells divide and differentiate into ciliated cells $[67,69,70,75,115]$. Cell proliferation has been shown to reach a maximum after 24$48 \mathrm{~h}$ exposure to $17 \mathrm{ppm} \mathrm{NO}_{2}$ and then to decline [67]. Recovery occurs more promptly in major bronchi than in terminal bronchioles, so the particular sensitivity of terminal bronchioles to oxidant gases may be explained by a lower reparative ability at this site of the airways [71]. Most of the early alterations which occur as a result of the exposure to $10-20 \mathrm{ppm} \mathrm{NO}_{2}$ are likely to recover totally after the cessation of exposure [70, 114].

After repair of the injury, animals can become tolerant to further continuous exposure of a similar entity to the previous one $[12,114]$. Furthermore, in continued exposure, a reduced level of inflammation has been observed after the first week [75, 86]. In this respect, the fact that $\mathrm{NO}_{2}$-induced emphysema is not aggravated by prolonged exposure [86], has been suggested to be due to the decrease in the number of neutrophils and to the increase of antioxidant activity with time.

\section{Biochemical alterations}

The biochemical alterations which occur in the respiratory system following exposure to oxidants include changes in lung lipids, antioxidant metabolism, and enzyme activity. Membrane polyunsaturated fatty acids and thiol groups seem to be the main biochemical targets of $\mathrm{NO}_{2}$ and $\mathrm{O}_{3}$.

Lipid peroxidation and antioxidative protective system. Both after short- and long-term exposure to $\mathrm{NO}_{2}$ or $\mathrm{O}_{3}$ at concentrations varying from 0.04 to $10 \mathrm{ppm}$, fatty acid peroxidation, which is considered an integral part of cell damage, has been demonstrated by the use of several markers of this reaction. Ethane exhalation in the breath has been measured in living animals, whilst in tissue homogenate the determination of the amount of tissue which reacts with thiobarbituric acid and of the content of conjugated dienes have been employed [116-121].

It has been suggested that the induction of the antioxidative protective system may be a compensatory cell mechanism against lipid peroxidation [116]. Indeed, the stimulation of the glutathione peroxidase system and of other protective enzymes, such as superoxide dismutase, disulphide reductase and 6-phosphogluconate dehydrogenase, is a response to short- or medium-term exposure to oxidants $[65,84,91,101,116,122,123]$. By contrast, this antioxidative protective enzymatic system is inhibited after long-term exposure to low levels of $\mathrm{NO}_{2}$ [117]. Therefore, one might speculate that the timecourse of such enzymatic changes may explain both why epithelial cells become more tolerant to oxidant gases after short- and medium-term exposure (i.e. during the stimulatory phase of protective enzymes) and why there is the development of emphysema and/or fibrosis after chronic exposure to $\mathrm{NO}_{2}$ (i.e. when the antioxidative protective enzymatic system is inhibited).

Membrane lipid peroxidation after exposure to $\mathrm{NO}_{2}$ is associated in rat airways with variations of vitamin $\mathrm{E}$ and nonprotein sulphydryl contents [116, 122]. Vitamin E administration may partially protect the cell from peroxidation induced by $\mathrm{O}_{3}$ and $\mathrm{NO}_{2}$, whereas its depletion increases peroxidative effects, probably because of its modulatory effect on the activity of antioxidative enzymes [80, 120, 124].

Other enzymatic activity. Other enzymatic alterations 
induced by oxidants involve the arachidonic acid cascade and the elastase-antielastase system.

Direct oxidant action and the products of peroxidative injury activate phospholipase $\mathrm{A}_{2}$ [125], and liberate arachidonic acid metabolites, such as $\mathrm{LTB}_{4}$ [126], prostaglandins $\mathrm{E}_{2}$ and $\mathrm{F}_{2 \alpha}$, and thromboxane $\mathrm{B}_{2}$ [127], which may play a role in the inflammatory response and in the induction of hyperresponsiveness.

The results of several studies suggest that an imbalance in elastase/antielastase is involved in the induction of the $\mathrm{NO}_{2}$-induced emphysema [86, 102, 111, 128-130]. Elastase release contributes to lesion development through connective tissue destruction, especially when the elastase inhibitory activity (most likely due to alpha ${ }^{-}$ proteinase inhibitors) is reduced. In rats chronically exposed to $\mathrm{NO}_{2}$, GLASGOW et al. [86] observed that the marked neutrophil recruitment was concomitant with an increased neutrophil elastase burden in the lung, which may directly contribute to lesion development. In hamsters, KLEINERMAN et al. [102] demonstrated an increased elastolytic activity dependent on increased number of alveolar macrophages recovered in bronchoalveolar lavage fluid from animals exposed to $30 \mathrm{ppm}$ of NO?. In both studies, the elastolytic secretion per cell seemed to be unaffected by exposure to NO,. Elastin content of the lung has been shown to decrease within 10 days during $\mathrm{NO}_{2}$ exposure [128] and its increased degradation can be detected by higher urinary desmosine levels [129]. Moreover, the soluble fraction of lung collagen increases during $\mathrm{NO}_{2}$ exposure, whereas the insoluble fraction, as well as total collagen, decreases [128, 130], suggesting that $\mathrm{NO}_{2}$ enhances the catabolism of lung collagen [130].

The results of these studies suggest that $\mathrm{NO}_{2}$-induced emphysema may be due to an impairment in elastaseantielastase. However, elastase-induced emphysema is worsened by the administration of beta-aminopropionitrile, an inhibitor of the lysyl oxidase, which in turn mediates the cross-linking reaction between collagen and elastin [109]. By contrast, aminopropionitrile neither increases the severity nor accelerates the timecourse of $\mathrm{NO}_{2}$-induced emphysema [111], suggesting that $\mathrm{NO}_{2}$ probably causes emphysema by inhibiting lysyl oxidase.

Exposure to $\mathrm{O}_{3}$ has been shown to produce an increase in the collagen synthesis and deposition, without effects on elastase activity and elastin content [32, 131, 132]. Since an increase in collagen is associated with fibrotic lesions, these observations may explain why fibrosis rather than emphysema develops in response to this oxidant.

\section{Impairment of lung defence}

Exposure to oxidants has been shown to affect lung defence mechanisms, as demonstrated both by a greater susceptibility to infections and altered immunological response.

Defence against infections. A reduced efficiency of the defence against infections is a well-documented effect of exposure both to $\mathrm{O}_{3}$ and $\mathrm{NO}_{2}$ at concentrations as low as 0.08 and $0.5 \mathrm{ppm}$, respectively, [133, 134].
Exposure to $\mathrm{NO}_{2}$ or $\mathrm{O}_{3}$ determines a dose-dependent increased susceptibility to and mortality from infectious agents [133-138]. A quantitative bacteriological monitoring of mice lung tissue has been used, which consists of infecting the animal with bacteria labelled with radioactive phosphorus, and of subsequent simultaneous measurement of pulmonary radioactive phosphorus and of bacterial concentrations. With this technique, it has been shown that lungs experimentally infected with labelled Staphylococcus aureus exert a reduced antibacterial activity when exposed to $\mathrm{NO}_{2}$ either before or after being infected [139]. The cellular target of $\mathrm{NO}_{2}$ and $\mathrm{O}_{3}$ exposure involved in pulmonary infections appears to be the alveolar macrophage [92, 138, 140, 141], which shows, both after single and combined exposures to $\mathrm{O}_{3}$ and $\mathrm{NO}_{2}$, changes in size and surface morphology, as well as decreased viability, substrate attachment ability, and decreased phagocytic and killing activity [92, 101, 138, 141, 142]. Moreover, the damage to ciliated epithelial cells described previously contributes to this $\mathrm{NO}_{2}$ and $\mathrm{O}_{3}$-induced impairment of the defence against infections.

Immunological response. It has also been reported that $\mathrm{O}_{3}$ and $\mathrm{NO}_{2}$ exposure can alter the pattern of the immunological response [136, 143-147]. An increased level of immunoglobulins in lung lavage fluid has been reported in mice after exposure to $\mathrm{O}_{3}$ [143]. In guinea-pigs, the appearance of serum antibody to normal lung tissue relates to the amount and duration of exposure to $\mathrm{NO}_{2}$, possibly as a consequence of an auto-antigenic effect of altered components of the lung tissue [144]. Furthermore, an altered antibody production has been observed in response to different antigenic stimuli [145-147]. These studies report either suppression or increase of the antibody responses. Contradictory results have also been obtained on cell-mediated immunological function, since both suppression and elevation of cellular responses have been observed [148, 149]. The actual effects of exposure to oxidants on the immune system remain to be understood; the observed discrepancies may depend on the mode of exposure, animal species or antigen employed.

$\mathrm{O}_{3}$ exposure has also been shown to reduce the antigen sensitization threshold in guinea-pigs [51]; animals exposed to $5 \mathrm{ppm} \mathrm{O}_{3}$ before sensitization need less ovalbumin to reach sensitization and show greater antibody production. Moreover, as reported above, when they are exposed after sensitization, the response to airway challenge occurs at lower antigen doses [49, 51]. Facilitation of sensitization to ovalbumin has also been reported after exposure to $40 \mathrm{ppm} \mathrm{NO}_{2}$ [150].

\section{Synergistic effects}

Interactions among toxic components of air pollution may occur, giving additive or synergistic (more than additive) effects. Potential interactions between $\mathrm{O}_{3}$ and $\mathrm{NO}_{2}$ and between each of these two oxidants and other pollutants at environmentally relevant concentrations should, therefore, be evaluated when setting air quality standards. Indeed, several animal studies have shown that synergistic toxicity does exist for most of the different effects exerted by these two oxidants. 
Simultaneous inhalation of $0.4 \mathrm{ppm} \mathrm{O}_{3}$ and $7 \mathrm{ppm} \mathrm{NO}_{2}$ for $6 \mathrm{~h}$ in rats causes a more than additive increase of epithelial cells recovered in bronchoalveolar lavage; permeability and inflammation (measured as protein and polymorphonuclear cells in the bronchoalveolar lavage fluid) are also synergistically augmented by simultaneous inhalation of slightly higher concentrations of oxidants (0.6-0.8 and 11-14 ppm of $\mathrm{O}_{3}$ and $\mathrm{NO}_{2}$, respectively) [151].

Biochemical studies have demonstrated that both peroxidation and enzymatic activity (superoxide dismutase, glutathione reductase and peroxidase, 6-phosphogluconate dehydrogenase, glucose-6-phosphate dehydrogenase) are potentiated when $\mathrm{NO}_{2}$ and $\mathrm{O}_{3}$ are administered simultaneously $[118,119,152]$. These biochemical responses are evoked even by exposures to $0.4 \mathrm{ppm}$ or less of $\mathrm{NO}_{2}$ and $\mathrm{O}_{3}$, concentrations at which both oxidants are unable to exert any effect on their own. An increased production of prostaglandins $E_{2}$ and $F_{2 \alpha 5}$ is also potentiated by exposure to a mixture of the two oxidants [127]. Moreover, some studies have shown that the effects exerted by $\mathrm{NO}_{2}$ and $\mathrm{O}_{3}$ on rate of collagen synthesis may be potentiated by simultaneous administration of acidic aerosols $[112,113]$.

Mortality caused by experimental infections with pathogens has also been studied following exposure to a mixture of $\mathrm{NO}_{2}$ and $\mathrm{O}_{3}$, and a synergistic effect has been observed, possibly because of the synergism exerted on the factors described above [136].

\section{In vitro studies}

The use of several techniques of investigation in vitro may contribute to a deeper understanding of the mechanisms underlying oxidant gas-induced injury. Effects on cells in culture and on whole isolated tissues have been widely analysed, focusing on the different aspects reviewed above, and have clarified some of the links between effects observed in vivo.

\section{Cell culture and mediator release}

To investigate the primary interaction occurring between cells and gases and the subsequent pathogenic events, in vitro systems in which isolated cells are exposed to oxidant gases have been developed [153-155]. The cell response to gases may be amplified by variations of cell culture conditions [156,157], so that comparison and extrapolation of results from these experiments to the in vivo exposures may be complicated. Nonetheless, similar results have been obtained by a comparative study on phagocytosis of alveolar macrophages obtained from rats exposed to 4-25 ppm $\mathrm{NO}_{2}$ in vivo and macrophages exposed in vitro to comparable gas concentrations [158].

Reduced viability after in vitro exposure to $\mathrm{O}_{3}$ has been observed on cultured cells [159-161]. Exposure to $\mathrm{O}_{3}$ induces cytoplasmic vacuolization, cell necrosis and lipid peroxidation in monolayer cultures of tracheal epithelium [161]. Lipid peroxidation and an alteration of membrane fluidity and properties after exposure to $\mathrm{O}_{3}$ and $\mathrm{NO}_{2}$ have been reported in epithelial and endothelial cells [161-163], fibroblasts [164], and macrophages $[159,165]$. Impaired membrane function seems, there- fore, an important aspect of oxidant-induced injury, as it may be the primary event of the development of pulmonary oedema.

Using alveolar macrophages cultured in aerobiosis, i.e. layered on porous membranes saturated by capillarity with culture medium and kept in direct contact with the atmosphere, it has been observed that cytotoxicity of oxidant gases, evaluated by morphological changes and by adenosine triphosphate cell content, is modulated by the antioxidant enzyme equipment and glutathione cell content [166]. Increase of phagocytic activity and of cytotoxicity toward mammary adenocarcinoma cells have been reported both in alveolar macrophages exposed to $10 \mathrm{ppm} \mathrm{NO}_{2}$ in vitro and in cells obtained from animals exposed in vivo to $40 \mathrm{ppm}$ [167]. By contrast, after longer in vitro or in vivo exposures to oxidant gases, alveolar macrophage superoxide anion production, mobility, phagocytosis, and bacterial killing decreases $[92,154,158,159,168]$.

The involvement of arachidonic acid metabolites in oxidant-induced injury is supported by in vitro studies, which show increased phosphatidylserine content and specific activation of phospholipase A in plasma membranes [1691, formation of cyclooxygenase and lipoxygenase product in epithelial cells [170, 171], and a concentration-dependent increase in release of prostaglandin $\mathrm{E}_{2}$ in alveolar cells [168, 172, 173]. Since exogenous prostaglandin $\mathrm{E}_{2}$ has been demonstrated to inhibit macrophage phagocytosis, it conceivably plays a role in the reduction of macrophage phagocytic activity induced by $\mathrm{O}_{3}$ [172]. Moreover, after $\mathrm{NO}_{2}$ exposure in standard cell cultures, alveolar macrophages have been shown to generate a neutrophil chemotactic factor identified as the $\mathrm{LTB}_{4}$ [126].

These data suggest that cell damage is a direct oxidant effect and that the oedema formation and the inflammatory response may be secondary events of oxidant-induced lung injury.

$\mathrm{O}_{3}$ also induces release of interleukin-6 and inhibits interleukin-2 release from lymphocytes [174, 175]; moreover, it inhibits mitogen-induced lymphocyte proliferation [175]. T-cell-dependent immunoglobin $\mathrm{G}(\mathrm{IgG})$ production also decreases after in vitro exposure of human lymphocytes to $\mathrm{O}_{3}$ [174]. These results suggest that oxidant-induced changes in immunoregulation may be mediated by an altered T-cell function.

\section{Tissue function}

Functional alterations induced by oxidants have also been investigated on isolated tissues.

Using the isolated saline perfused rat lung model, PINO et al. [176] demonstrated that $\mathrm{O}_{3}$ increases pulmonary resistance and decreases dynamic compliance. These functional alterations are accompanied by damage to airway epithelium and oedema, which resemble the lesions described after acute in vivo exposure, giving a further indication that inflammatory cells do not play a primary role in oxidant-induced lung injury.

In vitro airway smooth muscle responsiveness after in vivo exposure to oxidants has been studied to determine whether an alteration of the smooth muscle was involved in the effects exerted by these gases on lung 
function. After exposure to $\mathrm{O}_{3}$, preparations of airway smooth muscle develop in vitro an hyperresponsiveness to different stimuli, i.e. acetylcholine, electrical field stimulation, histamine and substance $\mathrm{P}$, which activate smooth muscle through activation of their own specific receptors. By contrast, the response to $\mathrm{KCl}$, which acts directly by depolarizing the plasma membrane, is not affected [177-179]. From these studies, it may be deduced that smooth muscle contractility is not altered, but that oxidants may affect airway responsiveness through alteration of receptor-mediated pathways. These studies have also suggested that the epithelium is involved in $\mathrm{O}_{3}$-induced hyperresponsiveness and that small airways are more susceptible. We have recently studied the in vitro response of rat bronchial rings after exposure to $\mathrm{NO}_{2}$ and we have found that this compound does not alter smooth muscle responsiveness $[180,181]$.

\section{Conclusions}

In conclusion, the studies reviewed in this article constitute a wide body of evidence about the adverse effects exerted on the respiratory system by the two most common pollutant oxidant gases. We have analysed the experimental data obtained from animal research, which allow some understanding of the mechanisms leading to health hazard. Once they have penetrated the airways, oxidant pollutants react with the epithelium lining fluid, possibly generating free radicals and other oxidant-diffusing products, which may then act on target cells. The main site of oxidant action is the terminal bronchiole, where epithelial cells and alveolar macrophages are damaged and produce mediators, leading to functional impairment, oedema and inflammation. Under these conditions, microbial infections are facilitated. Long-term exposure to oxidant gases may cause emphysema and/ or fibrosis, probably as a result of an altered metabolism of col- lagen and elastin. Throughout this cascade of events, a biochemical protective system is activated at cellular level, which may determine repair of the injury and development of tolerance to further exposures.

The relevance of insight from animal research to human health is an unresolved matter. Indeed, no animal species mimics humans in every aspect and a quantitative extrapolation to man of the effective pollutant concentration from animal studies is not appropriate. Nevertheless, several data from animal research have been taken into account when establishing air quality guidelines, mainly those obtained using long-term exposures and concentrations of gas that may presently be found in the environment. Indeed, results from experimental studies on humans (reviewed by SANDSTRÖM in this Series [182]) tally well with data from comparable experiments in animals. To emphasize the aspects which may be of greater relevance to man, we have summarized in table 1 the effects reported in animals after exposure to $\mathrm{NO}_{2}$ and $\mathrm{O}_{3}$ and the lowest gas concentrations which caused them.

With respect to the effects of ozone and nitrogen dioxide on the respiratory system, we would point out that: 1) high doses of both oxidants can cause death due to lung oedema; 2) sublethal short-term exposure to $\mathrm{NO}_{2}$ and $\mathrm{O}_{3}$ may cause reversible effects, such as altered lung function, airway hyperresponsiveness, epithelial damage, and inflammation; 3) long-term exposure may also cause irreversible damage, such as emphysema and pulmonary fibrosis; and 4) interactions either between $\mathrm{NO}_{2}$ and $\mathrm{O}_{3}$ or between one of them and other pollutants have synergistic effects.

The major impact of animal research is the understanding of the mechanisms of oxidant-induced respiratory injury, which may contribute to improve management and prevention of respiratory diseases associated with air pollution. Moreover, there is a continuous introduction of new pollutants into the atmosphere, which con-

Table 1. - Lower exposure concentrations of nitrogen dioxide and ozone which have been reported to cause adverse effects on the respiratory system in animals

\begin{tabular}{|c|c|c|c|c|c|c|}
\hline \multirow[t]{2}{*}{ Effect } & \multicolumn{3}{|c|}{ Nitrogen dioxide } & \multicolumn{3}{|c|}{ Ozone } \\
\hline & ppm & Time & [Ref.] & ppm & Time & [Ref.] \\
\hline Increased breathing frequency & 0.8 & \# & [40] & 0.34 & $2 \mathrm{~h}$ & [33] \\
\hline Decreased tidal volume & 5 & $2 \mathrm{~h}$ & [33] & 0.34 & $2 \mathrm{~h}$ & [33] \\
\hline Air trapping & $0.2(0.8)^{\# \#}$ & 32 weeks & [42] & 0.24 & $18 \mathrm{~h}$ & [34] \\
\hline Airflow limitation & $0.2(0.8)^{\# \#}$ & 32 weeks & [42] & 0.26 & $2 \mathrm{~h}$ & [39] \\
\hline Airway hyperresponsiveness & 4 & 7 days & [54] & 0.5 & $2 \mathrm{~h}$ & [38] \\
\hline Damage to epithelium & 2 & 2 years & [41] & $0.06(0.25)^{\# \#}$ & 1 week & [75] \\
\hline Lung oedema & 0.4 & 1 week & [106] & $0.06(0.25)^{\# \#}$ & 1 week & [75] \\
\hline Inflammation & 7 & 1 day & [66] & $0.06(0.25)^{\# \#}$ & 1 week & [75] \\
\hline Emphysematous lesions & 1 & 6 months & [13] & - & - & - \\
\hline Fibrotic lesions & 1 & 6 months & [13] & $0.06(0.25)^{\# \#}$ & 1 week & [75] \\
\hline Reduced defence against infections & 0.5 & 3 months & [137] & 0.08 & $3 \mathrm{~h}$ & [136] \\
\hline
\end{tabular}

N.B. For both oxidants, the same effects have been demonstrated after exposure to higher concentrations for shorter times. \#: This effect developed immediately and persisted with exposure, which lasted 2 yrs; \#\#: numbers are background exposure concentrations, while numbers between brackets are level of superimposed spike exposure. ppm: parts per million. 
stitutes a potential risk for human health. Experimental animal studies may help to quantify and possibly to prevent them. Finally, the research on the mechanisms of pulmonary toxicity of oxidant gases may provide useful information about the mechanisms of lung injury in general, and, thus, they may contribute to the understanding of respiratory diseases such as asthma, bronchitis, pulmonary fibrosis and emphysema.

Acknowledgements: The authors thank C. Howarth for editorial assistance and M. Lotti for reviewing scientific content.

\section{References}

1. Ciocco A, Thompson D. A follow-up of Donora ten years after. Am J Public Health 1961; 51: 155-164.

2. Shy CM, Goldsmith JR, Hackney JD, Lebowitz MD, Menzel DB. Health effect of air pollution. New York, American Lung Association, 1978.

3. Schwartz J, Marcus A. Mortality and air pollution in London: a time series analysis. Am J Epidemiol 1990; 131: $185-194$

4. Sexton K, Ryan PB. Assessment of human exposure to air pollution: methods, measurements and models. In: Watson AY, Bates RR, Kennedy D, eds. Air Pollution, the Automobile, and Public Health. Washington, DC, USA, National Academy Press, 1988; pp. 207-238.

5. Samet JM, Marbury MC, Spengler JD. Health effects and sources of indoor air pollution. Part I. Am Rev Respir Dis 1987; 136: 1486-1508.

6. Bresnitz EA, Rest KM. Epidemiologic studies of effects of oxidant exposure on human populations. In: Watson AY, Bates RR, Kennedy D, eds. Air Pollution, the Automobile, and Public Health. Washington, DC, USA, National Academy Press, 1988; pp. 389-413.

7. Mauderly JL, Samet JM. General environment. In: Crystal RG, West JB, Barnes PJ, Cherniack NS, Weibel ER, eds. The Lung: Scientific Foundations. New York, USA, Raven Press, 1991; pp. 1947-1960.

8. Warheit DB. Interspecies comparisons of lung responses to inhaled particles and gases. CRC Crirt Rev Toxicol 1989; 20: 1-29.

9. Fishbein L. Sources, nature and levels of air pollutants. In: Tomatis L, ed. Indoor and Outdoor Air Pollution and Human Cancer. Berlin Heidelberg, Germany, SpringerVerlag, 1993; pp. 17-66.

10. Seinfeld JH. Urban air pollution: state of the science. Science 1989; 243: 745-752.

11. Leaderer BP. Air pollutant emissions from kerosene space heaters. Science 1982; 218: 1113-1115.

12. United States Environmental Protection Agency. Air quality criteria for ozone and other photochemical oxidants. Washington, DC, USA, Report N. EPA-600/8- 84-020aF, US Government Printing Office, 1986.

13. United States Department of Health, Education, and Welfare. Criteria for a recommended standard... occupational exposure to oxides of nitrogen (nitrogen dioxide and nitric oxide). HEW publication No. (NIOSH) 76149, USA, 1976

14 World Health Organization. Air quality guidelines for Europe. Copenhagen, Denmark, WHO Regional Publications, European Series No. 23, 1987.

15. International Labour Organization. Occupational expo- sure limits for airborne toxic substances. Geneva, Switzerland, International Labour Office, Occupational Safety and Health Series No. 37, 1991.

16. Dahl AR, Schlesinger RB, Heck HD'A, Medinsky MA, Lucier GW. Comparative dosimetry of inhaled materials: differences among animal species and extrapolation to man. Fundam Appl Toxicol 1991; 16: 1-13.

17. Ultman JS. Transport and uptake of inhaled gases. In: Watson AY, Bates RR, Kennedy D, eds. Air Pollution, the Automobile, and Public Health. Washington, DC, USA, National Academy Press, 1988; pp. 323-366.

18. Overton JH, Miller FJ. Dosimetry modeling of inhaled toxic reactive gases. In: Watson AY, Bates RR, Kennedy D, eds. Air Pollution, the Automobile, and Public Health. Washington, DC, USA, National Academy Press, 1988; pp. 367-385.

19. Yokoyama E, Frank R. Respiratory uptake of ozone in dogs. Arch Environ Health 1972; 25: 132-138.

20. Santrock J, Hatch GE, Slade R, Hayes JM. Incorporation and disappearance of oxygen-18 in the lung from mice exposed to $1 \mathrm{ppm}{ }^{18} \mathrm{O}_{3}$. Toxicol Appl Pharmacol 1989; 98: 75-80.

21. Postlethwait EM, Bidani A. Reactive uptake governs the pulmonary air space removal of inhaled nitrogen dioxide. J Appl Physiol 1990; 68: 594-603.

22. Goldstein E, Peek NF, Parks NJ, Hines HH, Steffey EP, Tarkington B. Fate and distribution of inhaled nitrogen dioxide in Rhesus monkeys. Am Rev Respir Dis 1977; 115: 403-412.

23. Crapo J, Miller FJ, Mossman B, Pryor WA, Kiley JP. Environmental lung diseases: relationship between acute inflammatory responses to air pollutants and chronic lung disease. Am Rev Respir Dis 1992; 145: 1506-1512.

24. Postlethwait EM, Langford SD, Bidani A. Determinants of inhaled ozone absorption in isolated rat lungs. Toxicol Appl Pharmacol 1994; 125: 77-89.

25. Pryor WA. How far does ozone penetrate into the pulmonary air/tissue boundary before it reacts? Free Rad Biol Med 1992; 12: 83-88.

26. Pryor WA, Church DF. Aldehydes, hydrogen peroxide, and organic radicals as mediators of ozone toxicity. Free Rad Biol Med 1991; 11: 41-46.

27. Postlethwait EM, Langford SD, Bidani A. Reactive absorption of nitrogen dioxide by pulmonary epithelial lining fluid. J Appl Physiol 1990; 69: 523-531.

28. Saul RL, Archer MC. Nitrate formation in rats exposed to nitrogen dioxide. Toxicol Appl Pharmacol 1983; 67: 284-291.

29. Schlesinger RB. Comparative toxicity of ambient air pollutants: some aspects related to lung defense. Environ Health Perspect 1989; 81: 123-128.

30. Carson TR, Rosenholtz MS, Wilinski FT, Weeks MH. The responses of animals inhaling nitrogen dioxide for single, short-term exposure. Am Ind Hyg Assoc J 1962; 23: 457-462.

31. Gray EL, Patton FM, Goldberg SB, Kaplan E. Toxicity of the oxides of nitrogen. II. Acute inhalation toxicity of nitrogen dioxide, red fuming nitric acid, and white fuming nitric acid. Arch Ind Hyg Occup Med 1954; 10: 418-422.

32. Last JA. Biochemical and cellular interrelationships in the development of ozone-induced pulmonary fibrosis. In: Watson AY, Bates RR, Kennedy D, eds. Air Pollution, the Automobile, and Public Health. Washington, DC, USA, National Academy Press, 1988; pp. 415-440 .

33. Murphy SD, Ulrich CE, Frankowitz SH, Xintaras C. Altered function in animals inhaling low concentrations 
of ozone and nitrogen dioxide. Am Ind Hyg Assoc J 1964; 25: 246-253.

34. Inoue $\mathrm{H}$, Sato $\mathrm{S}$, Hirose $\mathrm{T}$, et al. A comparative study between functional and pathologic alterations in lungs of rabbits exposed to an ambient level of ozone: functional aspects. Nikkyo Shikkai-Shi 1979; 17: 288-296.

35. Lee LY, Dumont C, Djokic TD, Menzel TE, Nadel JA. Mechanism of rapid, shallow breathing after ozone exposure in conscious dogs. J Appl Physiol: Respirat Environ Exercise Physiol 1979; 46: 1108-1114.

36. Coleridge JCG, Coleridge HM, Schelegle ES, Green JF. Acute inhalation of ozone stimulates bronchial C-fibers and rapidly adapting receptors in dogs. J Appl Physiol 1993; 74: 2345-2352.

37. Schelegle ES, Car1 ML, Coleridge HM, Coleridge JCG, Green JF. Contribution of vagal afferents to respiratory reflexes evoked by acute inhalation of ozone in dogs. $J$ Appl Physiol 1993; 74: 2338-2344.

38. Abraham WM, Januszkiewicz AJ, Mingle M, Welker M, Wanner A, Sackner MA. Sensitivity of bronchoprovocation and tracheal mucous velocity in detecting airway responses to $\mathrm{O}_{3}$. J Appl Physiol: Respirat Environ Exercise Physiol 1980; 48: 789-793.

39. Watanabe S, Frank R, Yokoyama E. Acute effects of ozone on lungs of cats. I. Functional. Am Rev Respir Dis 1973; 108: 1141-1151.

40. Freeman G, Furiosi NJ, Haydon GB. Effects of continuous exposure of $0.8 \mathrm{ppm} \mathrm{NO}_{2}$ on respiration of rats. Arch Environ Health 1966; 13: 454456.

41. Freeman G, Stephens RJ, Crane SC, Furiosi NJ. Lesion of the lung in rats continuously exposed to two parts per million of nitrogen dioxide. Arch Environ Health 1968; 17: 181-192.

42. Miller FJ, Graham JA, Raub JA, et al. Evaluating the toxicity of urban patterns of oxidant gases. II. Effects in mice from chronic exposure to nitrogen dioxide. $J$ Toxicol Environ Health 1987; 21: 99-112.

43. Lee LY, Djokic TD, Dumont C, Graf PD, Nadel JA. Mechanism of ozone-induced tachypneic response to hypoxia and hypercapnia in conscious dogs. J Appl Physiol: Respirat Environ Exercise Physiol 1980; 48: 163-168.

44. Okazawa A, Kobayashi H, Imai T, et al. Ozone-induced airway hyperresponsiveness in guinea-pigs. Arerugi 1989; 38: $1217-1225$.

45. Lee LY, Bleecker ER, Nadel JA. Effect of ozone on bronchomotor response to inhaled histamine aerosol in dogs. J Appl Physiol: Respirat Environ Exercise Physiol 1977; 43: 626-631.

46. Holtzman MJ, Fabbri LM, Skoogh BE, et al. Time course of airway hyperresponsiveness induced by ozone in dogs. J Appl Physiol: Respirat Environ Exercise Physiol 1983; 55: $1232-1236$.

47. Murlas CG, Williams GJ, Lang Z, Chodimella V. Aerosolized neutral endopeptidase (NEP) reverses the increased airway reactivity to substance $\mathrm{P}$ caused by ozone. Am Rev Respir Dis 1990; 141 (Suppl.): A734.

48 Yanai M, Ohrui T, Aikawa T, et al. Ozone increases susceptibility to antigen inhalation in allergic dogs. J Appl Physiol 1990; 68: 2267-2273.

49. Campos MG, Segura $\mathrm{P}$, Vargas $\mathrm{MH}$, et al. $\mathrm{O}_{3}$-induced airway hyperresponsiveness to noncholinergic system and other stimuli. J Appl Physiol 1992; 73: 354-361.

50. Biagini RE, Moorman WJ, Lewis TR, Bernstein IL. Ozone enhancement of platinum asthma in a primate model. $\mathrm{Am}$ Rev Respir Dis 1986; 134: 719-725.

51. Sumitomo M, Nishikawa M, Fukuda T, et al. Effects of ozone exposure on experimental asthma in guinea-pigs sensitized with ovalbumin through the airways. Int Arch Allergy Appl Immunol 1990; 93: 139-147.

52. Holroyde MC, Norri AA. The effect of ozone on reactivity of upper and lower airways in guinea-pigs. $\mathrm{Br} J$ Pharmacol 1988; 94: 938-946.

53. Silbaugh SA, Mauderly JL, Macken CA. Effects of sulphuric acid and nitrogen dioxide on airway responsiveness of guinea-pig. J Toxicol Environ Health 1981; 8: $31-45$.

54. Kobayashi T, Shinozaki Y. Effect of subacute exposure to nitrogen dioxide on the airway responsiveness of guinea-pig. Agents Actions 1990; 31(Suppl.): 71-74.

55. Matsui S, Jones GL, Woolley MJ, Lane CG, Gontovnick LS, O'Byrne PM. The effect of antioxidants on ozoneinduced airway hyperresponsiveness in dogs. Am Rev Respir Dis 1991; 144: 1287-1290.

56. Fabbri LM, Aizawa H, O'Byrne PM, et al. An antiinflammatory drug (BW755C) inhibits airway hyperresponsiveness induced by ozone in dogs. J Allergy Clin Immunol 1985; 76: 162-166.

57. O'Byrne PM, Walters EH, Aizawa H, Fabbri LM, Holtzrnan MJ, Nadel JA. Indomethacin inhibits the airway hyperresponsiveness but not the neutrophil influx induced by ozone in dogs. Am Rev Respir Dis 1984; 130: 220-224.

58. Aizawa H, Chung KF, Leikauf GD, et al. Significance of thromboxane generation in ozone-induced airway hyperresponsiveness in dogs. J Appl Physiol 1985; 59: 1918-1923.

59. Chitano P, Di Stefano A, Finotto S, et al. Ambroxol inhibits airway hyperresponsiveness induced by ozone in dogs. Respiration 1989; 55 (Suppl. 1): 74-78.

60. Okazawa A, Kobayashi H, Adachi M, Takahashi T, Misawa M. The effect of leukotriene $\mathrm{C}_{4} / \mathrm{D}_{4}$ receptor antagonist (ONO1078) and thromboxane $\mathrm{A}_{2}$ synthetase inhibitor (OKY-046) on airway hyperresponsiveness induced by ozone exposure in guinea-pigs. Nippon Kyobu Shikkan Gakkai Zasshi 1990; 28: 293-299.

61. Gordon T, Taylor BF, Amdur MO. Ozone inhibition of tissue cholinesterase in guinea-pigs. Arch Environ Health 1981; 36: 284-288.

62. Schultheis AH, Bassett DJP, Fryer AD. Ozone-induced airway hyperresponsiveness and loss of neuronal $\mathrm{M}_{2}$ muscarinic receptor function. J Appl Physiol 1994; 76: 1088-1097.

63. Yeadon M, Wilkinson D, Darley-Usmar V, O'Leary VJ, Payne AN. Mechanisms contributing to ozone-induced bronchial hyperreactivity in guinea-pigs. Pulmonary Pharmacol 1992; 5: 39-50.

64. Stephens RJ, Freeman G, Crane SC, Furiosi NJ. Ultrastructural changes in the terminal bronchiole of the rat during continuous, low-level exposure to nitrogen dioxide. Exp Mol Pathol 1971; 14: 1-19.

65. Rombout PJA, Dormans JAMA, Van Bree L, Marra M. Structural and biochemical effects in lungs of Japanese quail following a 1 week exposure to ozone. Environ Res 1991; 54: 39-51.

66. Gordon RE, Shaked AA, Solano DF. Taurine protects hamster bronchioles from acute $\mathrm{NO}_{2}$-induced alterations: a histologic, ultrastructural, and freeze-fracture study. $A m$ J Pathol 1986; 125: 585-600.

67. Stephens RJ, Freeman G. Evans MJ. Early response of lungs to low levels of nitrogen dioxide. Arch Environ Health 1972; 24: 160-179.

68. Freeman G, Crane SC, Furiosi NJ, Stephens RJ, Evans MJ, Moore WD. Covert reduction in ventilatory surface in rats during prolonged exposure to subacute nitrogen 
dioxide. Am Rev Respir Dis 1972; 106: 563-579.

69. Stephens RJ. Evans MJ, Sloan MF, Freeman G. A comprehensive ultrastructural study of pulmonary injury and repair in the rat resulting from exposures to less than one ppm ozone. Chest 1974; 65 (Suppl.): 11S-13s

70. Rombout PJA, Dormans JAMA, Marra M, Van Esch GJ. Influence of exposure regimen on nitrogen dioxide-induced morphological changes in the rat lung. Environ Res 1986; 41: 466-480.

71. Kawakami M, Yasui S, Yamawaki I, Katayama M, Nagai A, Takizawa T. Structural changes in airways of rats exposed to nitrogen dioxide intermittently for seven days: comparison between major bronchi and terminal bronchioles. Am Rev Respir Dir 1989; 140: 1754-1762.

72. Chang LY, Mercer RR, Stockstill BL, et al. Effects of low levels of $\mathrm{NO}_{2}$ on terminal bronchiolar cells and its relative toxicity compared to $\mathrm{O}_{3}$ Toxicol Appl Pharmacol 1988; 96: 451-464.

73. Boatman ES, Sato S, Frank R. Acute effects of ozone on cat lungs. II. Structural. Am Rev Respir Dis, 1974; 110: $157-169$.

74. Cabral-Anderson LJ, Evans MJ, Freeman G. Effects of $\mathrm{NO}_{2}$ on the lungs of aging rats. I. Morphology. Exp Mol Pathol 1977; 27: 353-365.

75. Chang LY, Huang Y, Stockstill BL, et al. Epithelial injury and interstitial fibrosis in the proximal alveolar regions of rats chronically exposed to a simulated pattern of urban ambient ozone. Toxicol Appl Pharmacol 1992; 115: 241-252.

76. Juhos LT, Green DP, Furiosi NJ, Freeman G. A quantitative study of stenosis in the respiratory bronchiole of the rat in $\mathrm{NO}_{2}$-induced emphysema. Am Rev Respir Dis 1980; 121: 541-549.

77. Freeman G, Haydon GB. Emphysema after low-level exposure to $\mathrm{NO}_{2}$. Arch Environ Health 1964; 8: 125-128.

78. Barr BC, Hyde DM, Plopper CG, Dungworth DL. Distal airway remodelling in rats chronically exposed to ozone. Am Rev Respir Dis 1988; 137: 924-938.

79. Suzuki E, Takahashi Y, Aida S, Kimula Y, Ito Y, Miura $\mathrm{T}$. Alteration in surface structure of Clara cells and pulmonary cytochrome $\mathrm{P}-450 \mathrm{~b}$ level in rats exposed to ozone. Toxicology 1992; 71: 223-232.

80. Plopper CG, Dungworth DL, Tyler WS, Chow CK. Pulmonary alterations in rats exposed to 0.2 and $0.1 \mathrm{ppm}$ ozone: a correlated morphological and biochemical study. Arch Environ Health 1979; 34: 390-395.

81. Meulenbelt J, Dormans JAMA, Marra M, Rombout PJA, Sangster B. Rat model to investigate the treatment of acute nitrogen dioxide intoxication. Hum Exp Toxicol 1992: 11: 179-187.

82. Pino MV, Levin JR, Stovall MY, Hyde DM. Pulmonary inflammation and epithelial injury in response. to acute ozone exposure in the rat. Toxicol Appl Pharmacol 1992; 112: 64-72.

83. Guth DJ, Warren DL, Last JA. Comparative sensitivity of measurements of lung damage made by bronchoalveolar lavage after short-term exposure of rats to ozone. Toxicology 1986; 40: 131-143.

84. Meulenbelt J, Van Bree L, Dormans JAMA, Boink ABTJ, Sangster B. Biochemical and histological alterations in rats after acute nitrogen dioxide intoxication. Hum Exp Toxicol 1992; 11: 189-200.

85. Pino MV, Stovall MY, Levin JR, Devlin RB, Koren HS, Hyde DM. Acute ozone-induced lung injury in neutrophil-depleted rats. Toxicol Appl Pharmacol 1992; 114: 268-276.

86. Glasgow JE, Pietra GG, Abrams WR, Blank J, Oppenheim
DM, Weinbaum G. Neutrophil recruitment and degranulation during induction of emphysema in the rat by nitrogen dioxide. Am Rev Respir Dis 1987; 135: $1129-1136$.

87. Man SFP, Williams DJ, Amy RA, Man GCW, Lien DC. Sequential changes in canine pulmonary epithelial and endothelial cell functions after nitrogen dioxide. Am Rev Respir Dis 1990; 142: 199-205.

88. Bhalla DK, Crocker 'TT. Pulmonary epithelial permeability in rats exposed to $\mathrm{O}_{3}$. J Toxicol Environ Health 1987; 21: 73-87.

89. Vassilyadi M, Michel RP. Pattern of fluid accumulation in $\mathrm{NO}_{2}$-induced pulmonary edema in dogs: a morphometric study. Am J Pathol 1988; 130: 10-21.

90. Guidotti TL. Toxic inhalation of nitrogen dioxide: morphologic and functional changes. Exp Mol Pathol 1980; 33: 90-103.

91. De Nicola DB, Rebar AH, Henderson RF. Early damage indicators in the lung. V. Biochemical and cytological response to $\mathrm{NO}_{2}$ inhalation. Toxicol Appl Pharmacol 1981; 60: 301-312.

92. Driscoll KE, Vollmuth TA, Schlesinger RB. Acute and subchronic ozone inhalation in the rabbit: response of alveolar macrophages. J Toxicol Environ Health 1987; 21: $27-43$.

93. Holtzman MJ, Fabbri LM, O'Byrne PM, et al. Importance of airway inflammation for hyperresponsiveness induced by ozone. Am Rev Respir Dis 1983; 127: 686-690.

94. Fabbri LM, Aizawa H, Alpert SE, et al. Airway hyperresponsiveness and changes in cell counts in bronchoalveolar lavage after ozone exposure in dogs. Am Rev Respir Dis 1984; 129: 288-291.

95. Hyde DM, Hubbard WC, Wong V, Wu R, Pinkerton $\mathrm{K}$, Plopper CG. Ozone-induced acute tracheobronchial epithelial injury: relationship to granulocyte emigration in the lung. Am J Respir Cell Mol Biol 1992; 6: 481-497.

96. Daniel EE, O'Byrne P. Autonomic nerves and airway smooth muscle: effect of inflammatory mediators on airway nerves and muscle. Am Rev Respir Dis 1991; 143 (Suppl.): S3-S5.

97. Henson PM, Johnston RB Jr. Tissue injury in inflammation: oxidants, proteinases, and cationic proteins. $J$ Clin Invest 1987; 79: 669-674.

98. Weiss SJ. Tissue destruction by neutrophils. $N$ Engl $J$ Med 1989; 320: 365-376.

99. Bleavins MR, Dziedzic D. An immunofluorescence study of T- and B-lymphocytes in ozone-induced pulmonary lesions in the mouse. Toxicol Appl Pharmacol 1990; 105: 93-102.

100. Dziedzic D, Wright ES, Sargent NE. Pulmonary reponse to ozone: reaction of bronchus-associated lymphoid tissue and lymph node lymphocytes in the rat. Environ Res 1990; 51: 194-208.

101. Mochitate K, Ishida K, Ohsumi T, Miura T. Long-term effects of ozone and nitrogen dioxide on the metabolism and population of alveolar macrophages. J Toxicol Environ Health 1992; 35: 247-260.

102. Kleinerman J, Ip MPC, Sorensen J. Nitrogen dioxide exposure and alveolar macrophage elastase in hamsters. Am Rev Respir Dis 1982; 125: 203-207.

103. Young C, Bhalla DK. Time course of permeability changes and PMN flux in rat trachea following $\mathrm{O}_{3}$ s exposure. Fundam Appl Toxicol 1992, 18: 175-180.

104. Bhalla DK, Daniels DS, Luu NT. Attenuation of ozoneinduced airway permeability in rats by pretreatment with cyclophosphamide, FPL55712, and indomethacin. Am J 
Respir Cell Mol Biol 1992; 7: 73-80.

105. Kleeberger SR, Hudak BB. Acute ozone-induced change in airway permeability: role for infiltrating leukocytes. J Appl Physiol 1992, 72: 670-676.

106. Sherwin RP, Carlson DA. Protein content of lung lavage fluid of guinea-pigs exposed to $0.4 \mathrm{ppm}$ nitrogen dioxide. Arch Environ Health 1973; 27: 90-93.

107. O'Byrne PM, Walters EH, Gold BD, et al. Neutrophil depletion inhibits airway hyperresponsiveness induced by ozone exposure. Am Rev Respir Dis 1984; 130: 214-219.

108. Li ZY, O'Byrne PM, Lane CG, Arnaout MA, Daniel EE. The effect of an anti-CD1lb/CD18 monoclonal antibody on ozone-induced neutrophil influx and airway hyperresponsiveness in dogs. Am Rev Respir Dis 1991; 143 (Suppl.): A43.

109. Snider GL, Lucey EC, Stone PJ. Animal models of emphysema. Am Rev Respir Dis 1986; 133: 149-169.

110. Karlinsky JB, Snider GL. Animal models of emphysema. Am Rev Respir Dis 1978; 117: 1109-1133.

111. Blank J, Glasgow JE, Pietra GG, Burdette L, Weinbaum G. Nitrogen dioxide-induced emphysema in rats: lack of worsening by beta-aminopropionirile treatment. Am Rev Respir Dis 1988; 137: 376-379.

112. Last JA, Gerriets JE, Hyde DM. Synergistic effects on rat lungs of mixtures of oxidant air pollutants (ozone or nitrogen dioxide) and respirable aerosols. Am Rev Respir Dis 1983; 128: 539-544.

113. Last JA, Hyde DM, Guth DJ, Warren DL. Synergistic interaction of ozone and respirable aerosols on rat lungs. I. Importance of aerosol acidity. Toxicology 1986; 39: 247-257.

114. Evans MJ, Cabral-Anderson LJ, Freeman G. Effects of $\mathrm{NO}_{2}$ on the lungs of aging rats. II. Cell proliferation. Exp Mol Pathol 1977; 27: 366-376.

115. Evans MJ, Johnson LV, Stephens RJ, Freeman G. Renewal of the terminal bronchiolar epithelium in the rat following exposure to $\mathrm{NO}_{2}$ or $\mathrm{O}_{3}$. Lab Invest 1976; 35: 246-257.

116. Sagai M, Ichinose T, Oda H, Kubota K. Studies on biochemical effects of nitrogen dioxide. II. Changes of the protective systems in rat lungs and of lipid peroxidation by acute exposure. J Toxicol Environ Health 1982; 9: $153-164$.

117. Sagai M, Ichinose T, Kubota K. Studies on the biochemical effects of nitrogen dioxide. IV. Relation between the change of lipid peroxidation and the antioxidative protective system in rat lungs upon life span exposure to low levels of $\mathrm{NO}_{2}$. Toxicol Appl Pharmacol 1984; 73 : $444-456$.

118. Ichinose T, Sagai M. Biochemical effects of combined gases of nitrogen dioxide and ozone. III. Synergistic effects on lipid peroxidation and antioxidative protective systems in the lungs of rats and guinea pigs. Toxicology 1989; 59: 259-270.

119. Sagai M, Ichinose T. Biochemical effects of combined gases of nitrogen dioxide and ozone. IV. Changes of lipid peroxidation and antioxidative protective systems in rat lungs upon life span exposure. Toxicology 1991; 66: 121-132.

120. Thomas HV, Mueller PK, Lyman RL. Lipoperoxidation of lung lipids in rats exposed to nitrogen dioxide. Science 1968; 159: 532-534.

121. Cavanagh DG, Morris JB. Mucus protection and airway peroxidation following nitrogen dioxide exposure in the rat. J Toxicol Environ Health 1987; 22: 313-328.

122. Ichinose T, Sagai M. Studies on biochemical effects of nitrogen dioxide. III. Changes of the antioxidative protective systems in rat lungs and of lipid peroxidation by chronic exposure. Toxicol Appl Pharmacol 1882; 66: 1-8.
123. Chow CK, Dillard CJ, Tappel AL. Glutathione peroxidase system and lysozyme in rats exposed to ozone or nitrogen dioxide. Environ Res 1974; 7: 311-317.

124. Elsayed NM, Mustafa MG. Dietary antioxidants and the biochemical response to oxidant inhalation. I. Influence of dietary vitamin $\mathrm{E}$ on the biochemical effects of nitrogen dioxide exposure in rat lung. Toxicol Appl Pharmacol 1982; 66: 319-328.

125. Van Kuijk FJGM, Sevanian A, Handelman GJ, Dratz EA. A new role for phospholipase $\mathrm{A}_{2}$ : protection of membranes from lipid peroxidation damage. Trends Biochem Sci 1987; 12: 31-34.

126. Robinson TW, Duncan DP, Forman HJ. Chemoattractant and leukotriene $\mathrm{B}_{4}$ production from rat alveolar macrophages exposed to nitrogen dioxide. Am J Respir Cell Mol Biol 1990: 3: 21-26.

127. Schlesinger RB, Driscoll KE, Gunnison AF, Zelikoff JT. Pulmonary arachidonic acid metabolism following acute exposure to ozone and nitrogen dioxide. J Toxicol Environ Health 1990; 31: 275-290.

128. Kleinerman J, Ip MPC. Effects of nitrogen dioxide on elastin and collagen contents of lung. Arch Envir Health 1979; 34: 228-232.

129. Ip MPC, Kleinerman J, Collins A. Desmosine concentrations in urine and lung as and index of $\mathrm{NO}_{2}$-induced lung injury. Fed Proc 1984; 43: A700.

130. Drozdz M, Kucharz E, Sjyia J. Effect of chronic exposure to nitrogen dioxide on collagen content in lung and skin of guinea-pigs. Environ Res 1977; 13: 369-377.

131. Last JA, Greenberg DB, Castleman WL. Ozone-induced alterations in collagen metabolism of rat lungs. Toxicol Appl Pharmacol 1979; 51: 247-258.

132. Last JA, Gelzleichter T, Harkema J, Parks WC, Mellick P. Effects of 20 months of ozone exposure on lung collagen in Fischer 344 rats. Toxicology 1993; 84: 83-102.

133. Miller FJ, Illing JW, Gardner DE. Effect of urban ozone levels on laboratory-induced respiratory infections. Toxicol Lett 1978; 2: 163-169.

134. Ehrlich R, Henry MC. Chronic toxicity of nitrogen dioxide. I Effect on resistance to bacterial pneumonia. Arch Environ Health 1968; 17: 860-865.

135. Graham JA. Gardner DE, Blommer EJ, House DE, Ménache MG, Miller FJ. Influence of exposure patterns of nitrogen dioxide and modifications by ozone on susceptibility to bacterial infectious disease in mice. J Toxicol Environ Health 1987; 21: 113-125.

136. Pennington JE. Effects of automotive emissions on susceptibility to respiratory infections. In: Watson AY, Bates RR, Kennedy D, eds. Air pollution, the automobile, and public health. Washington, DC, USA, National Academy Press, 1988: pp. 499-518.

137. Henry MC, Findlay J, Spangler J, Ehrlich R. Chronic toxicity of $\mathrm{NO}_{2}$ in squirrel monkeys. III. Effect on resistance to bacterial and viral infection. Arch Environ Health 1970; 20: 566-570.

138. Gilmour MI, Park P, Selgrade MK. Ozone-enhanced pulmonary infection with Streptococcus zooepidemicus in mice: the role of alveolar macrophage function and capsular virulence factors. Am Rev Respir Dis 1993; 147: 753-760.

139. Goldstein E, Eagle MC, Hoeprich PD. Effect of nitrogen dioxide on pulmonary bacterial defense mechanisms. Arch Environ Health 1973; 26: 202-204.

140. Davis JK, Davidson MK, Schoeb TR, Lindsey JR. Decreased intrapulmonary killing of Mycoplasma pulmonis after short-term exposure to $\mathrm{NO}_{2}$ is associated with damaged alveolar macrophages. Am Rev Respir Dis 1992; 145: 406-411. 
141. Schlesinger RB. Intermittent inhalation of nitrogen dioxide: effects on rabbit alveolar macrophages. J Toxicol Envir Health 1987; 21: 127-139.

142. Dormans JAMA, Rombout PJA, Van Loveren H. Surface morphology and morphometry of rat alveolar macrophages after ozone exposure. J Toxicol Environ Health 1990; 31: $53-70$.

143. Osebold JW, Owens SL, Zee YC, Dotson WM, LaBarre DD. Immunological alterations in the lungs of mice following ozone exposure: changes in immunoglobulin levels and antibody-containing cells. Arch Environ Health 1979: 34: 258-265.

144. Balchum OJ, Buckley RD, Sherwin R, Gardner M. Nitrogen dioxide inhalation and lung antibodies. Arch Environ Health 1965; 10: 274-277.

145. Fenters JD, Findlay JC, Port CD, Ehrlich R, Coffin DL. Chronic exposure to nitrogen dioxide: immunologic, physiologic, and pathologic effects in virus-challenged squirrel monkeys. Arch Environ Health 1973; 27: 85-89.

146. Fujimaki H, Shimizu F. Effects of acute exposure to nitrogen dioxide on primary antibody response. Arch Environ Health 1981; 36: 114-119.

147. Fujimaki H. Impairment of humoral responses in mice exposed to nitrogen dioxide and ozone mixtures. Environ Res 1989; 48: 211-217.

148. Maigetter RZ, Fenters JD, Findlay JC, Ehrlich R, Gardner DE. Effect of exposure to nitrogen dioxide on T- and Bcells in mouse spleens. Toxicol Lett 1978; 2: 157-161.

149. Hillam RP, Bice DE, Hahn FF, Schnizlein CT. Effects of acute nitrogen dioxide exposure on cellular immunity after lung immunization. Environ Res 1983; 31: 201-211.

150. Matzumura Y. The effects of ozone, nitrogen dioxide, and sulfur dioxide on the experimentally-induced allergic respiratory disorder in guinea-pigs. I. The effect on sensitization with albumin through the airways. Am Rev Respir Dis 1970; 102: 430-437.

151. Gelzleichter TR, Witschi H, Last JA. Synergistic interaction of nitrogen dioxide and ozone on rat lungs: acute responses. Toxicol Appl Pharmacol 1992; 116: 1-9.

152. Lee JS, Mustafa MG, Afifi AA. Effects of short-term, single and combined exposure to low-level $\mathrm{NO}_{2}$ and $\mathrm{O}_{3}$ on lung tissue enzyme activities in rats. J Toxicol Environ Health 1990; 29: 293-305.

153. Rasmussen $R E$. In vitro systems for exposure of lung cells to $\mathrm{NO}_{2}$ and $O_{3}$. J Toxicol Environ Health 1984; 13: 397-411.

154. Valentine R. An in vitro system for exposure of lung cells to gases: effects of ozone on rat macrophages. $J$ Toxicol Environ Health 1985; 16: 115-126.

155. Aerts C, Voisin C, Wallaert B. Type II alveolar epithelial cell in vitro culture in aerobiosis. Eur Respir J 1988; 1: 738-747.

156. Cheek JM, Postlethwait EM, Crandall ED. Effects of culture conditions on susceptibility of alveolar epithelial cell monolayers to $\mathrm{NO}_{2}$. Toxicol Lett 1988; 40: 247-255.

157. Hosselet JJ. Comparison of metabolic and functional activities of alveolar macrophage cultured in liquid or gaseous phase. Thesis of Medicine, University of Nantes, 1989.

158. Hooftman RN, Kuper CF, Appelman LM. Comparative sensitivity of histopathology and specific lung parameters in the detection of lung injury. J Appl Toxicol 1988; 8: 59-65.

159. Banks MA, Porter DW, Martin WG, Castranova V. Effects of in vitro ozone exposure on peroxidative damage, membrane leakage, and taurine content of rat alveolar macrophages. Toxicol Appl Pharmacol 1990; 105. $55-65$.
160. Mayer D, Branscheid D. Exposure of human lung fibroblasts to ozone: cell mortality and hyaluronan metabolism. J Toxicol Environ Health 1992; 35: 235-246.

161. Alpert SE, Kramer CM, Hayes MM, Dennery PA. Morphologic injury and lipid peroxidation in monolayer cultures of rabbit tracheal epithelium exposed in vitro to ozone. J Toxicol Environ Health 1990; 30: 287-304.

162. Patel JM, Block ER. Nitrogen dioxide-induced changes in cell membrane fluidity and function. Am Rev Respir Dis 1986; 134: 1196-1202.

163. Cheek JM, Kim KJ, Crandall ED. $\mathrm{NO}_{2}$ decreases paracellular resistance to ion and solute flow in alveolar epithelial monolayers. Exp Lung Res 1990; 16: 56 $1-575$.

164. Van der Zee J, Dubbelman TMAR, Van Steveninck J. Toxic effects of ozone on murine L929 fibroblasts. Damaging action on transmembrane transport systems. Biochem J 1987; 245: 301-304.

165. Rietjens IMCM Van Tilburg CAM, Coenen TMM, Alink GM, Konings AWT. Influence of polyunsaturated fatty acid supplementation and membrane fluidity on ozone and nitrogen dioxide sensitivity of rat alveolar macrophages. J Toxicol Environ Health 1987; 21: 45-56.

166. Voisin C. Aerts C, Wallaert B. Prevention of in vitro oxidant-mediated alveolar macrophage injury by cellular glutathione and precursors. Bull Eur Physiopathol Respir 1987; 23: 309-313.

167. Sone S, Brennan LM, Creasia DA. In vivo and in vitro $\mathrm{NO}_{2}$ exposures enhance phagocytic and tumoricidal activities of rat alveolar macrophages. J Toxicol Environ Health 1983; II: 151-153.

168. Becker S, Madden MC, Newman SL, Devlin RB, Koren HS. Modulation of human alveolar macrophage properties by ozone exposure in vitro. Toxicol Appl Pharmacol 1991; 110: 403-415.

169. Sekharam KM, Patel JM, Block ER. Plasma membranespecific phospholipase A1 activation by nitrogen dioxide in pulmonary artery endothelial cells. Toxicol Appl Pharmacol 1991; 107: 545-554.

170. Leikauf GD, Driscoll KE, Wey HE. Ozone-induced augmentation of eicosanoid metabolism in epithelial cells from bovine trachea. Am Rev Respir Dis 1988; 137: 435-442.

171. McKinnon KP, Madden MC, Noah TL, Devlin RB. In vitro ozone exposure increases release of arachidonic acid products from a human bronchial epithelial cell line. Toxicol Appl Pharmacol 1993; 118: 215-223.

172. Canning BJ, Hmieleski RR, Spannhake EW, Jakab GJ. Ozone reduces murine alveolar and peritoneal macrophage phagocytosis: the role of prostanoids. Am J Physiol 1991; 261: L277-L282.

173. Friedman M, Madden MC, Samet JM, Koren HS. Effects of ozone exposure on lipid metabolism in human alveolar macrophages. Environ Health Perspect 1992; 97: 95-101.

174. Becker S, Quay J, Koren HS. Effect of ozone on immunoglobulin production by human B-cells in vitro. J Toxicol Environ Health 1991; 34: 353-366.

175. Becker S, Jordan R, Orlando GS, Koren HS. In vitro ozone exposure inhibits mitogen-induced lymphocyte proliferation and IL-2 production. $J$ Toxicol Environ Health 1989; 24: 469-483.

176. Pino MV, McDonald RJ, Berry JD, Joad JP, Tarkington BK, Hyde DM. Functional and morphologic changes caused by acute ozone exposure in the isolated and perfused rat lung. Am Rev Respir Dis 1992; 145: 882-889. 
177. Walters EH, O'Byrne PM, Graf PD, Fabbri LM, Nadel JA. The responsiveness of airway smooth muscle in vitro from dogs with airway hyperresponsiveness in vivo. Clin Sci 1986; 71: 605-611.

178. Beckett WS, Black C, Turner C, Spannhake EWM, Menkes HA. In vivo exposure to ozone causes increased in vitro responses of small airways. Am Rev Respir Dis 1988; 137: 1236-1238.

179. Murlas CG, Murphy TP, Chodimella V. $\mathrm{O}_{3}$-induced mucosa-linked airway muscle hyperresponsiveness in the guinea-pig. J Appl Physiol 1990; 69: 7-13.
180. Chitano P, Mapp CE, Boniotti A, et al. Short-term exposure of rats to nitrogen dioxide $\left(\mathrm{NO}_{2}\right)$ does not change bronchial smooth muscle responses in vitro. Am Rev Respir Dis 1993; 147 (Suppl.): A924.

181. Chitano P, Boniotti A, Papi A, et al. Rat bronchial smooth muscle responses in vitro after long-term exposure to nitrogen dioxide. Eur Respir J 1993; 6 (Suppl.): 330s.

182. Sandström T. Respiratory effects of air pollutants: experimental studies in humans. Eur Respir J 1995: 8: 976-995. 